\title{
Acute Effects of Hexavalent Chromium on Survival, Oxygen Consumption, Hematological Parameters and Some Biochemical Profiles of the Indian Major Carp, Labeo rohita
}

\author{
S. S. Vutukuru ${ }^{1 *}$ \\ ${ }^{1}$ Environmental and Molecular Toxicology Lab, Centre for Environment, Institute of Science and Technology, Jawaharlal \\ Nehru Technological University, Kukatpally, Hyderabad-500 072, Andhra Pradesh, India \\ *Correspondence to Dr. Sesha Srinivas Vutukuru. Email: myvutukuru@yahoo.com
}

Received: 20 May 2005 / Accepted: 07 October 2005 / Published: 30 December 2005

\begin{abstract}
An attempt has been made in the present investigation to determine the acute toxicity of hexavalent chromium and its toxicological effects on survival, physiological, hematological and biochemical parameters of the widely consumed Indian major carp, Labeo rohita. Short-term acute toxicity tests were performed adopting renewal bioassay technique (USEPA, 1975) over a period of 96h, using different concentrations of potassium dichromate to the fish and the $96 \mathrm{~h} \mathrm{LC}_{50}$ value was found to be $111.45 \mathrm{mg} / 1\left(\mathrm{Cr}^{+6}\right.$ as $\left.39.40 \mathrm{mg} / \mathrm{l}\right)$. ANOVA results showed that the normal respiratory activity of the fish was significantly affected and there is a depression in the metabolic rate at the end of 24, 48, 72 and 96h exposure. The metal also induced significant decrease $(p<0.001)$ in the hematological parameters of the fish like total erythrocyte count, hemoglobin percent and absolute value Mean cell hemoglobin $(\mathrm{MCH})$ both at the end of $24 \mathrm{~h}$ and $96 \mathrm{~h}$ exposure indicating anemia. Appreciable decline in the biochemical profiles such as total glycogen, total lipids and total protein contents of the fish was also observed. However, the decrease in protein content was significant only at the end of $96 \mathrm{~h}$. This study reflects the extent of the toxic effects of hexavalent chromium and the metal induced cumulative deleterious effects at various functional levels in the widely consumed freshwater fish, Labeo rohita.
\end{abstract}

Keywords: Chromium ${ }^{+6}$, Labeo rohita, acute effects, oxygen consumption, hematological indices, biochemical profiles.

\section{Introduction}

Freshwaters are highly vulnerable to pollution since they act as immediate sinks for the consequences of human activity always associated with the danger of accidental discharges or criminal negligence. Heavy metals constitute a core group of aquatic pollutants and additional concentrations of these metals accumulate in the aquatic ecosystems as a result of land-based activities [1]. Fish mostly have a tendency to bio-accumulate heavy metals and humans can be at great risk sometimes even lethal, through contamination of the food chain [2]. Chromium continues to be in widespread use in industry, paints, metal plating as corrosion inhibitor and its particulates enter the aquatic medium through effluents discharged from tanneries, textiles, electroplating, mining, dyeing, and printing industries, photographic and pharmaceutical industries. In the environment, chromium exists primarily in the trivalent and hexavalent forms but the hexavalent form predominates the trivalent form in natural waters. $\mathrm{Cr}$ (VI) compounds have been found to be mutagenic and carcinogenic in a variety of test systems. Chromium is also a compound of biological interest, probably having a role in glucose and lipid metabolism as an essential nutrient [3].

Information on the acute toxic effects of hexavalent chromium on survival and physiology of fishes is limited in Indian context [4-9] and its effects on the widely consumed Indian major carp, Labeo rohita which forms an important link in the aquatic food chain are not known. Knowledge of acute toxicity of a xenobiotic often can be very helpful in predicting and preventing acute damage to aquatic life in receiving waters as well as in regulating toxic waste discharges [10]. In view of this, short-term acute toxicity tests were performed on Labeo rohita over a period of $96 \mathrm{~h}$ to determine the $\mathrm{LC}_{50}$ value so as to elucidate the acute effects of hexavalent chromium on the survival, oxygen consumption, haematological parameters and some biochemical constituents of the fish. The corresponding results are 
discussed in this paper and compared with those in other fishes exposed to various other metallic and environmental stressors.

\section{Materials and Methods}

\section{Acute Toxicity Tests}

Labeo rohita were obtained from the Government Fish Farm at Nidubrolu town $\left(16^{0} .5^{\prime} \mathrm{N} ; 80^{\circ} .5^{\prime} \mathrm{E}\right)$ and healthy fish were acclimated in the laboratory for 15 days in plastic pools of 100 litres capacity containing well-aerated unchlorinated groundwater before they were used for experiments. The feeding and maintenance of the fish and the physico-chemical characteristics of water used for acclimation, controls and experimentation were given earlier [11]. Short-term tests of acute toxicity over a period of $96 \mathrm{~h}$ were performed on the fish following renewal bioassay. Only fishes which were healthy and showed active movements were used for the tests. Experiments were performed only on fingerlings (total length 5-6 cm and total weight 2-3 g).

Desired concentrations of potassium dichromate (Excelar grade, Qualigens, Mumbai, India) were prepared by adding aliquots of $1 \%$ stock solution in double distilled water. The toxicant solution in the test chambers was replaced with fresh solution of same concentration every 24 hours. Renewal bioassays were conducted using five concentrations of potassium dichromate viz., $80 \mathrm{mg} / 1 ; 100 \mathrm{mg} / \mathrm{l} ; 120 \mathrm{mg} / \mathrm{l} ; 140 \mathrm{mg} / \mathrm{l}$ and $150 \mathrm{mg} / \mathrm{l}$ which resulted in mortality of the fish within the range of five to $95 \%$. Ten fishes (in two batches of five each) were tested at each concentration and the loading was at the recommended level [12]. Controls without toxicant were also run simultaneously. The behaviour and condition of the fishes was noted every $24 \mathrm{~h}$ up to $96 \mathrm{~h}$. Between the experiments, the test chambers (15 litre capacity) were carefully washed to eliminate residual metal adsorption to the walls. Fishes that failed to respond even to strong tactile stimuli were considered dead and removed immediately. No differentiation was made between sexes.

\section{Statistical Analysis}

The experiments were repeated thrice and only the arithmetic mean of the three experiments at each concentration was taken to express the results. Probit analysis of $\log$ dose against response (mortality) was performed adopting standard protocol (13). The regression equations were calculated by the method of least squares and $96 \mathrm{~h}_{50}$ value was derived from the equation.

\section{Oxygen Consumption}

Since respiratory distress is one of the important manifestations of acute heavy metal toxicity and is known to produce physiological imbalance, Labeo rohita were exposed to $96 \mathrm{~h} \mathrm{LC}_{50}$ concentration of chromium. In the present study, the respiration rate of the same fish was measured from $24 \mathrm{~h}$ to $96 \mathrm{~h}$ with a $24 \mathrm{~h}$ interval. At the end of $24 \mathrm{~h}$ exposure, each fish was transferred from the test chamber ( 51 capacity) to respiratory chamber of 1 litre capacity, which is also numbered in accordance with the test chamber. The fish were allowed to stabilize for five minutes and then the experiment was run for a period of $1 \mathrm{~h}$. After the experiment, the fishes were replaced in their respective test chambers. The same procedure was repeated for $48 \mathrm{~h}, 72 \mathrm{~h}$ and $96 \mathrm{~h}$. Any dead fish during the course of the experiment was removed and the test repeated so as to get the response of at least three fishes. Controls were also run simultaneously to obtain information on the oxygen consumption of the fish in normal state. At the end of 96h, the fishes were sacrificed, blotted dry and weighed to the nearest $\mathrm{mg}$ to calculate the metabolic rate. Respiratory measurements were made by the method adopted by Fitch [14] and the dissolved oxygen was estimated adopting Winkler's method. The oxygen consumed by the fish is expressed as $\mathrm{mgO}_{2} / \mathrm{g}$ and metabolic rate as $\mathrm{mg} \mathrm{O}_{2} / \mathrm{g} / \mathrm{h}$. The respiratory measurements were made in diffused daylight and the time of the experiment was kept constant (11.00 am to $3.00 \mathrm{pm}$ ) to avoid the effect of time of day on the respiration of the fish. The temperature and $\mathrm{pH}$ during the course of the experiments were $27^{\circ} \pm 1^{\circ} \mathrm{C}$ and $8.0 \pm 0.5$, respectively. ANOVA was employed to test the significance between the individual fishes and effect of time and unpaired Student's ' $t$ ' test was applied to find the significance of difference between the means of control and exposed fishes [15].

\section{Hematological Studies}

Twenty fish (in two batches of 10 each) were exposed separately to $96 \mathrm{~h} \mathrm{LC}_{50}$ concentration of chromium $(39.40 \mathrm{mg} / \mathrm{l})$ for both 24 and $96 \mathrm{~h}$. Controls were also run simultaneously. After a $24 \mathrm{~h}$ exposure, five fish from those that survived the exposure were removed; blotted dry and their tails were severed at the caudal peduncle with a sterilized surgical blade for blood samples. The initial drops were discarded and fresh blood was collected in small vials (anticoagulated with $0.02 \mathrm{ml}$ of $10 \%$ EDTA). The blood samples were analyzed separately for each fish for hemoglobin percent by acid-hematin method of Sahli in hemometer (Germany) and the erythrocytes were enumerated in Naeubaur's double hemocytometer [16]. The mean cell hemoglobin $(\mathrm{MCH})$ was directly calculated from these values. The same procedure was followed for the other group exposed for $96 \mathrm{~h}$. The experiment was repeated thrice and only the arithmetic mean of the three tests was considered. The hemoglobin percent is expressed as $\mathrm{g} \%$, TEC as $10^{6} / \mathrm{mm}^{3}$ and $\mathrm{MCH}$ as picograms. Unpaired Student's ' $t$ ' test was employed to compare the mean values of control and exposed fishes.

\section{Biochemical Studies}

Twenty fish (total length $5.9-6.5 \mathrm{~cm}$ and total weight 2.5-3.1 g) in two batches of ten each were exposed separately for $24 \mathrm{~h}$ and $96 \mathrm{~h}$ to $39.40 \mathrm{mg} / \mathrm{l}$ of chromium. Five fish from those that survived the exposure were sacrificed both at the end of $24 \mathrm{~h}$ and $96 \mathrm{~h}$, blotted dry and weighed. They were later dissected to isolate the whole liver (30-40 mg), muscle $(250 \mathrm{mg})$ and whole gill (80$100 \mathrm{mg}$ ) tissues. The tissues were dried for $24 \mathrm{~h}$ in a hot air oven at $50^{\circ} \mathrm{C}$. The dry tissues were weighed to the 
nearest mg. The tissues of the control fishes $(n=5)$ were also processed similarly for biochemical analysis. The biochemical parameters viz., glycogen, total lipid and total protein were analyzed by adopting universally accepted standard protocols [17-19], respectively. The biochemical constituents were expressed as mg per gram dry weight of the tissue and only the arithmetic mean values $(n=5)$ are presented to express the results. The mean values of the control and the exposed fishes are compared following ' $t$ ' test.

\section{Results and Discussion}

\section{Survival}

The concentrations of potassium dichromate tested in the present study were $80 \mathrm{mg} / \mathrm{l}(\mathrm{Cr}$ as $28.30 \mathrm{mg} / \mathrm{l}), 100$ $\mathrm{mg} / \mathrm{l}(\mathrm{Cr}$ as $35.40 \mathrm{mg} / \mathrm{l}), 120 \mathrm{mg} / \mathrm{l}(\mathrm{Cr}$ as $42.42 \mathrm{mg} / \mathrm{l})$, $140 \mathrm{mg} / \mathrm{l}(\mathrm{Cr}$ as $49.50 \mathrm{mg} / \mathrm{l})$ and $150 \mathrm{mg} / \mathrm{l}(\mathrm{Cr}$ as 53.03 $\mathrm{mg} / \mathrm{l})$. The mortality ranged from $10 \%$ to $93.3 \%$ and increased with a corresponding increase in the toxicant concentration and also duration of the exposure demonstrating both time and concentration dependent responses.

\section{Behavioural Manifestations}

The behaviour and condition of the fishes in both the control and test solution was noted every $24 \mathrm{~h}$ up to $96 \mathrm{~h}$. The fishes showed a marked change in their behaviour when exposed to different concentrations of the test solution. In lower concentrations of potassium dichromate viz., $80 \mathrm{mg} / \mathrm{l}$ and $100 \mathrm{mg} / \mathrm{l}$ the fishes showed rapid swimming than in control. Behavioural manifestations of acute toxicity like copious secretion of mucus, loss of scales, discoloration, surfacing and darting movements were observed in Labeo rohita exposed to higher concentrations of potassium dichromate viz., $120 \mathrm{mg} / \mathrm{l}, 140 \mathrm{mg} / \mathrm{l}$ and $150 \mathrm{mg} / \mathrm{l}$ from $48 \mathrm{~h}$ to $96 \mathrm{~h}$. After $72 \mathrm{~h}$ exposure, the fishes exhibited lethargy and erratic swimming suggesting loss of equilibrium at higher concentrations. At the time of death transient hyperactivity was also observed.

The regression equation of the expected Probit (Y) and $\log$ concentration $(\mathrm{X})$ is $\mathrm{Y}=(\overline{\mathrm{y}}-\mathrm{bx})+\mathrm{bx}=10.23 \mathrm{X}$ - 15.94. The $96 \mathrm{~h} \mathrm{LC}_{50}$ value for potassium dichromate was derived directly from the regression equation and is found to be $111.45 \mathrm{mg} / \mathrm{l}(\mathrm{Cr}$ as $39.40 \mathrm{mg} / \mathrm{l})$ and the $95 \%$ fiducial limits are $101.92 \mathrm{mg} / \mathrm{l}(\mathrm{Cr}$ as $36.03 \mathrm{mg} / \mathrm{l})$ and $121.87 \mathrm{mg} / \mathrm{l}(\mathrm{Cr}$ as $43.08 \mathrm{mg} / \mathrm{l})$. It is evident that the relationship between log concentration and empirical probability is positive and linear indicating that the percentage mortality increased with an increase in toxicant concentration and also duration of the exposure.

The reaction and survival of aquatic animals depend on not only the biological state of the animals and physico-chemical characteristics of water but also on kind, toxicity, type and time of exposure to the toxicant. In the present study, the mortality increased with an increase in concentration and also the duration of the exposure. Behavioural manifestations of acute toxicity in Labeo rohita were more or less similar to those reported in other fishes exposed to chromium [20]. A summary of acute toxicity of chromium to Labeo rohita and other fishes indicates that Labeo rohita is more susceptible to chromium than other fishes (Table 1). The differences in the $96 \mathrm{~h} \mathrm{LC}_{50}$ values between Labeo rohita and other fishes may be attributed to the fact that metal induced changes in physiology and survival of aquatic organisms under metallic stress is complicated because such changes differ from metal to metal, species to species and from one experimental condition to another. The exact causes of death due to heavy metal poisoning are multiple and depend mainly on time-concentration combinations. However, there is no clear-cut explanation on the exact mode of action of different metals causing the mortality in aquatic animals. It is possible that cumulative action of chromium at various metabolic sites could be responsible for the mortality of Labeo rohita.

Table 1: A summary of acute toxicity of chromium to icthyofauna

\begin{tabular}{|c|c|c|c|c|c|c|}
\hline Species & $\begin{array}{l}\text { Exposure } \\
\text { period }\end{array}$ & Results & $\begin{array}{c}\text { Exposure } \\
\text { type }\end{array}$ & Temperature & Test conditions & Reference \\
\hline Labeo rohita & $96 \mathrm{~h} \mathrm{LC}_{50}$ & $39.40 \mathrm{mg} / 1$ & Renewal & $27.5^{0} \pm 1^{0} \mathrm{C}$ & $\begin{array}{c}\mathrm{PH}=8.0 \pm .5 ; \mathrm{CO}_{3}=61 \mathrm{mg} / \mathrm{l} \\
\mathrm{HCO}_{3}=301 \mathrm{mg} / \mathrm{l} ; \\
\text { Alkalinity }=501 \mathrm{mg} / 1\end{array}$ & Present study \\
\hline $\begin{array}{l}\text { Pimephales } \\
\text { promelas }\end{array}$ & $96 \mathrm{~h} \mathrm{LC}_{50}$ & $48 \mathrm{mg} / 1$ & $\begin{array}{l}\text { Flow } \\
\text { through }\end{array}$ & $25^{0} \mathrm{C}$ & $\begin{array}{c}\mathrm{PH}=7.5 \text { to } 7.9 \\
\mathrm{Alk}=200-230 \mathrm{mg} / \mathrm{l}\end{array}$ & {$[35]$} \\
\hline Carassius auratus & $96 \mathrm{~h} \mathrm{LC}_{50}$ & $120 \mathrm{mg} / \mathrm{l}$ & $\begin{array}{l}\text { Flow } \\
\text { through }\end{array}$ & $25^{\circ} \mathrm{C}$ & $\begin{array}{c}\mathrm{PH}=7.5 \text { to } 7.9 ; \\
\mathrm{Alk}=200-230 \mathrm{mg} / 1\end{array}$ & {$[35]$} \\
\hline $\begin{array}{l}\text { Pimephales } \\
\text { promelas }\end{array}$ & $96 \mathrm{~h} \mathrm{LC}_{50}$ & $61 \mathrm{mg} / 1$ & $\begin{array}{l}\text { Flow } \\
\text { through }\end{array}$ & $15^{\circ} \mathrm{C}$ & $\begin{array}{c}\mathrm{PH}=7.6-8.2 ; \\
\mathrm{Alk}=230-232 \mathrm{mg} / \mathrm{l}\end{array}$ & {$[36]$} \\
\hline $\begin{array}{l}\text { Pimephales } \\
\text { promelas }\end{array}$ & $96 \mathrm{~h} \mathrm{LC}_{50}$ & $52 \mathrm{mg} / 1$ & $\begin{array}{l}\text { Flow } \\
\text { through }\end{array}$ & $15^{\circ} \mathrm{C}$ & $\begin{array}{c}\mathrm{PH}=7.6-8.2 ; \\
\mathrm{Alk}=230-232 \mathrm{mg} / 1\end{array}$ & {$[36]$} \\
\hline $\begin{array}{l}\text { Salvelinus } \\
\text { fontinalis }\end{array}$ & $96 \mathrm{hLC}_{50}$ & $59 \mathrm{mg} / \mathrm{l}$ & $\begin{array}{l}\text { Flow } \\
\text { through }\end{array}$ & $12^{\circ} \mathrm{C}$ & $\begin{array}{c}\mathrm{PH}=7.0-8.0 ; \\
\text { Hardness }=44-46 \mathrm{mg} / \mathrm{l}\end{array}$ & {$[37]$} \\
\hline Salmp gardnerii & $96 \mathrm{~h} \mathrm{LC}_{50}$ & $69 \mathrm{mg} / \mathrm{l}$ & $\begin{array}{l}\text { Flow } \\
\text { through }\end{array}$ & $12^{\circ} \mathrm{C}$ & $\begin{array}{c}\mathrm{PH}=7.0-8.0 ; \\
\text { Hardness }=44-46 \mathrm{mg} / 1\end{array}$ & {$[37]$} \\
\hline Channa punctatus & $96 \mathrm{~h} \mathrm{LC}_{50}$ & $50 \mathrm{mg} / 1$ & Static & $29.8^{0} \mathrm{C} \pm 1^{0} \mathrm{C}$ & $\mathrm{PH}=7.5-8.5$ & {$[6]$} \\
\hline Catla catla & $96 \mathrm{~h} \mathrm{LC}_{50}$ & $100 \mathrm{mg} / 1$ & Static & $28^{0} \mathrm{C} \pm 1^{0} \mathrm{C}$ & $\mathrm{PH}=7.1 ; \mathrm{CO}_{3}=604 \mathrm{mg} / 1$ & {$[26]$} \\
\hline
\end{tabular}

* Source: Brungs et al. Effects of pollution on freshwater fishes. Journal W.P.C.F. 1977, Washington D.C, 49, $1425-1493$. 


\section{Oxygen Consumption}

The mean metabolic rates of the control and exposed fishes at the end of $24 \mathrm{~h}, 48 \mathrm{~h}, 72 \mathrm{~h}$ and $96 \mathrm{~h}$ along with the percent decrease from control are given (Table 2 ). It is clear from the results that the metabolic rate of Labeo rohita exposed to chromium decreased from control with an increase in the exposure period from $24 \mathrm{~h}$ to $96 \mathrm{~h}$. The action of heavy metals on the respiratory function of fishes appears to be diversified. Alteration in the cellular components as cause of depression in the respiratory activity of fishes exposed to acute metallic stress has been suggested [21-22]. Inhibition of the respiratory enzymes in fishes exposed to heavy metals was also reported [23]. ANOVA employed to investigate the effect of time and variation among the individual fishes exposed to chromium showed that the metabolic differences between the individual fishes, at any given exposure period are not significant whereas the effect of time on the metabolic rate is significant.

Table 2: Effect of $96 \mathrm{~h} \mathrm{LC}_{50}$ concentration of potassium dichromate $(111.45 \mathrm{mg} / \mathrm{l} ; \mathrm{Cr}$ as $39.40 \mathrm{mg} / \mathrm{l})$ on the metabolic rate $\left(\mathrm{mgO}_{2} / \mathrm{g} / \mathrm{h}\right)$ of Labeo rohita at the end of 24, 48, 72 and $96 \mathrm{~h}$

\begin{tabular}{lcccc}
\hline $\begin{array}{l}\text { Period of } \\
\text { Exposure }\end{array}$ & $\begin{array}{c}\text { Control } \\
\mathrm{X} \pm \mathrm{SD}\end{array}$ & $\begin{array}{c}\text { Experiment } \\
\mathrm{X} \pm \mathrm{SD}\end{array}$ & $\begin{array}{c}\text { Percent } \\
\text { Change }\end{array}$ & Result \\
\hline $24 \mathrm{~h}$ & & $0.587 \pm 0.07$ & -16.50 & $P<0.05$ \\
& & & & \\
$48 \mathrm{~h}$ & 0.703 & $0.508 \pm 0.07$ & -27.74 & $P<0.01$ \\
& \pm & & & \\
$72 \mathrm{~h}$ & 0.08 & $0.453 \pm 0.05$ & -35.56 & $P<0.01$ \\
& & $0.309 \pm 0.05$ & -56.05 & $P<0.01$ \\
\hline
\end{tabular}

A perusal of the available information reveals that heavy metal induced alterations in the respiratory function of fishes differ not only from metal to metal but also the sites of action. The decrease in the oxygen consumption of Labeo rohita exposed to chromium indicates the onset of acute hypoxia under metallic stress. Further, the fact that the drop in metabolic rate of the fish as a protective measure to ensure that there is a low intake of toxic substance also cannot be ruled out. Reduced oxygen consumption at higher concentrations of heavy metals could also arise as a result of respiratory inhibiting factors that come into play. In the present study, copious mucous secretion and bulging of gills was observed. The drop in the metabolic rate of Labeo rohita exposed to chromium can also be attributed to clogging of gills by mucous. Gills are vital respiratory and osmoregulatory organs and cellular damage induced by the metal might impair the respiratory function of the fish by reducing the respiratory surface area. Architectural changes in the gill morphology like formation of club shaped gill lamellae; fusion and necrosis of the gill lamellae and atrophy of central axis of the gill filament were observed in Labeo rohita under the toxic impact of chromium [24]. These findings clearly suggest decreased respiratory surface area, which can also account for the drop in the metabolic rate of the fish.

\section{Hematological Studies}

The hemoglobin percent, total erythrocyte count and mean cell hemoglobin in Labeo rohita exposed to $96 \mathrm{~h} \mathrm{LC}_{50}$ concentration of chromium for $24 \mathrm{~h}$ and $96 \mathrm{~h}$ are given in (Table 3). The decrease in hemoglobin per cent and TEC from control are significant at the end of both 24 and $96 \mathrm{~h}$ exposure periods. Further this decrease in the hemoglobin percent and TEC is relatively highly significant at the end of $96 \mathrm{~h}$ when compared to the $24 \mathrm{~h}$. Hematological indices are very important parameters for the evaluation of fish physiological status under metallic stress.

Table 3: Effect of $96 \mathrm{~h} \mathrm{LC}_{50}$ concentration of hexavalent chromium $(39.40 \mathrm{mg} / \mathrm{l})$ on hemoglobin per cent, total erythrocyte count and mean cell hemoglobin of control and exposed Labeo rohita for $24 \mathrm{~h}$ and $96 \mathrm{~h}(\mathrm{n}=15)$

\begin{tabular}{|c|c|c|c|c|c|}
\hline Parameter Studied & $\begin{array}{l}\text { Period } \\
\text { (h) }\end{array}$ & $\begin{array}{l}\text { Control } \\
X \pm S D\end{array}$ & $\begin{array}{c}\text { Experiment } \\
X \pm S D\end{array}$ & $\begin{array}{l}\text { Percent } \\
\text { Change }\end{array}$ & Result \\
\hline Hemoglobin (g \%) & & $8.1 \pm 0.67$ & $6.80 \pm 0.76$ & -16.05 & $P<0.05^{*}$ \\
\hline $\begin{array}{l}\text { Total erythrocyte } \\
\text { count }\left(10^{6} / \mathrm{mm}^{3}\right)\end{array}$ & 24 & $1.3 \pm 0.03$ & $1.05 \pm 0.05$ & -17.43 & $P<0.05^{*}$ \\
\hline $\begin{array}{l}\text { Mean cell } \\
\text { hemoglobin }(\mathrm{Pg})\end{array}$ & & $63.6 \pm 0.5$ & $64.6 \pm 0.72$ & +1.67 & $P>0.05 \#$ \\
\hline Hemoglobin (g \%) & & $8.1 \pm 0.67$ & $4.40 \pm 0.55$ & -45.68 & $P<0.001^{* *}$ \\
\hline $\begin{array}{l}\text { Total erythrocyte } \\
\text { count }\left(10^{6} / \mathrm{mm}^{3}\right)\end{array}$ & 96 & $1.3 \pm 0.03$ & $0.76 \pm 0.19$ & -40.66 & $P<0.001 * *$ \\
\hline $\begin{array}{l}\text { Mean cell } \\
\text { hemoglobin }(\mathrm{Pg})\end{array}$ & & $63.6 \pm 0.5$ & $58.2 \pm 0.45$ & -8.46 & $P<0.05^{*}$ \\
\hline
\end{tabular}

** Highly significant; * Significant; \# Not significant 
The changes in blood indices and their peculiarities depend on the concentrations of heavy metals and duration of exposure of fish to them. Hematological indices are of different sensitivity to various environmental factors and chemicals. The count of erythrocytes is quite a stable index and the fish body tries to maintain this count within the limits of physiological standards, using various physiological mechanisms of compensation, especially under stress. The hemoglobin concentrations reflect the supply of an organism with oxygen and the organism itself tries to maintain them as much stable as possible. Short-term exposures to low concentrations of heavy metals mostly induce an increase in these hematological indices. Increase in RBC number and hematocrit level was reported in Mystus vittatus exposed to sub-lethal and lethal concentrations of copper and zinc [25]. High concentrations of heavy metals or long-term exposure of fish to their sub-lethal concentrations usually decrease the above-mentioned indices. Earlier works also reported a fall in RBC count, hemoglobin percent and packed cell volume and decrease in $\mathrm{MCH}, \mathrm{MCHC}$ and $\mathrm{MCV}$ in freshwater fishes exposed to cadmium, zinc and nickel indicating anemia, erythropenia and leucopoiesis [26-28].

The TEC, hemoglobin per cent and mean cell hemoglobin $(\mathrm{MCH})$ were appreciably declined in Labeo rohita exposed to chromium reflecting the anemic state of the fish which could be possibly due to iron deficiency and its consequent decreased utilization for hemoglobin synthesis. This is in accordance with a similar study on Labeo rohita, which also reported hypo chromic microlytic anemia under lead chloride stress [29]. Anemia in fish is an early manifestation of acute and chronic intoxication of chromium. Further, a significant decrease in TEC, hemoglobin per cent, $\mathrm{MCH}$ and hematocrit were also reported in Channa punctatus exposed to both copper and chromium and this decrease is more pronounced in fishes exposed to chromium suggesting that the metal induces acute anemia under toxic conditions [9]. In the present study, the anemia could be probably due to structural alterations of heme leading to disturbed hemoglobin synthesis and also the inhibitory effect of chromium on the enzyme system in the synthesis of hemoglobin cannot be ruled out as suggested in earlier studies [30].

\section{Biochemical Studies}

The glycogen, total lipid and total protein levels in liver, muscle and gill of control fish and of Labeo rohita exposed to the $96 \mathrm{hr} \mathrm{LC}_{50}$ concentration of chromium for 24 and $96 \mathrm{~h}$ were presented (Tables 4 and 5). It is clear from the results that there is an appreciable decline in different biochemical constituents of the fish under chromium stress. The decrease in the glycogen concentration of the tissues of Labeo rohita can be due to its enhanced utilization as an immediate source to meet energy demands under metallic stress. It could also be due to the prevalence of hypoxic or anoxic conditions, which normally enhances glycogen utilization [31]. Enhanced utilization of glycogen and its consequent depletion in tissues may be attributed to hypoxia since it increases carbohydrate consumption. Under hypoxic conditions, the animal derives its energy from anaerobic breakdown of glucose, which is available to the cells by the increased glycogenolysis [32]. In the present study the metabolic rate of Labeo rohita was significantly dropped indicating hypoxia that probably have resulted in a shift to anaerobic glycolytic pathway by increased glycogenolysis. Depleted glycogen levels following chromium stress reported in Cyprinus carpio communis [4] under hypoxic conditions also supports this view. A consistent decrease in tissue glycogen reserves observed in this study also suggests impaired glycogenesis. Further, the decline in glycogen might be partly due to its utilization in the formation of glycoproteins and glycolipids, which are essential constituents of various cells and other membranes. Decrease in tissue lipid and proteins were also observed in Labeo rohita exposed to chromium.

Table 4: Effect of $96 \mathrm{~h} \mathrm{LC}_{50}$ concentration of hexavalent chromium $(39.40 \mathrm{mg} / \mathrm{l})$ on total glycogen, total lipid and total protein concentration of liver, muscle and gill of Labeo rohita (mg per gram dry weight) at the end of $24 \mathrm{~h}$ exposure $(n=5)$

\begin{tabular}{lccccc}
\hline $\begin{array}{l}\text { Bio-chemical } \\
\text { Constituent }\end{array}$ & Tissue & $\begin{array}{c}\text { Control } \\
\mathrm{X} \pm \text { S.D }\end{array}$ & $\begin{array}{c}\text { Experiment } \\
\mathrm{X} \pm S . D\end{array}$ & Percent Change & Result \\
\hline \multirow{3}{*}{ Glycogen } & Liver & $21.01 \pm 1.02$ & $19.16 \pm 0.46$ & -8.80 & $P<0.05^{* *}$ \\
& Muscle & $7.46 \pm 0.54$ & $5.72 \pm 0.39$ & -23.32 & $P<0.05^{* *}$ \\
& Gill & $4.13 \pm 0.16$ & $3.48 \pm 0.48$ & -15.74 & $P>0.05 \#$ \\
Total lipids & Liver & $67.15 \pm 7.85$ & $52.71 \pm 2.11$ & -21.50 & $P<0.05^{* *}$ \\
& Muscle & $135.78 \pm 5.01$ & $123.78 \pm 2.65$ & -8.84 & $P<0.05^{* *}$ \\
& Gill & $59.25 \pm 6.50$ & $50.23 \pm 3.64$ & -15.22 & $P<0.05^{*}$ \\
Total protein & Liver & $128.55 \pm 12.90$ & $120.71 \pm 5.81$ & -6.10 & $P>0.05 \#$ \\
& Muscle & $274.70 \pm 7.65$ & $272.50 \pm 7.43$ & -0.81 & $P>0.05 \#$ \\
& Gill & $203.29 \pm 3.91$ & $195.55 \pm 2.10$ & -3.91 & $P>0.05 \#$ \\
\hline
\end{tabular}

\footnotetext{
* Significant; ** Highly significant; \# Not significant
} 
Table 5: Effect of $96 \mathrm{~h} \mathrm{LC}_{50}$ concentration of hexavalent chromium (39.40) $\mathrm{mg} / \mathrm{l}$ ) on glycogen, total lipid and total protein content of liver, muscle and gill of Labeo rohita (mg per gram dry weight) at the end of 96 h exposure $(n=5)$

\begin{tabular}{lccccc}
\hline $\begin{array}{l}\text { Bio-chemical } \\
\text { Constituent }\end{array}$ & Tissue & $\begin{array}{c}\text { Control } \\
8 \pm \text { S.D }\end{array}$ & $\begin{array}{c}\text { Experiment } \\
8 \pm S . D\end{array}$ & Percent Change & Result \\
\hline \multirow{2}{*}{ Glycogen } & Liver & $17.08 \pm 1.25$ & $7.70 \pm 0.95$ & -54.91 & $P<0.001^{*}$ \\
& Muscle & $5.18 \pm 0.17$ & $2.26 \pm 0.27$ & -56.37 & $P<0.001^{*}$ \\
& Gill & $2.28 \pm 0.44$ & $1.39 \pm 0.14$ & -39.04 & $P<0.001^{*}$ \\
Total lipids & Liver & $58.46 \pm 3.16$ & $32.94 \pm 1.98$ & -43.65 & $P<0.001^{*}$ \\
& Muscle & $131.89 \pm 1.31$ & $92.50 \pm 4.64$ & -29.87 & $P<0.001^{*}$ \\
& Gill & $55.10 \pm 2.60$ & $40.48 \pm 1.24$ & -26.53 & $P<0.001^{*}$ \\
Total protein & Liver & $122.39 \pm 4.41$ & $102.83 \pm 5.56$ & -15.98 & $P<0.001^{*}$ \\
& Muscle & $267.46 \pm 8.64$ & $252.55 \pm 5.74$ & -5.58 & $P<0.05 \#$ \\
& Gill & $192.79 \pm 2.06$ & $171.78 \pm 3.64$ & -10.90 & $P<0.001^{*}$ \\
\hline
\end{tabular}

* Highly Significant; \# Significant

The decrease in tissue lipid and proteins might be partly due to their utilization in cell repair and tissue organization with the formation of lipoproteins, which are important cellular constituents of cell membranes, and cell organelles present in cytoplasm [33]. Decrease in the lipid concentration observed in the present study can also be attributed to its utilization in cell repair and tissue organization. The depletion in tissue proteins of Labeo rohita may be due to impaired or low rate of protein synthesis under metallic stress or due to their utilization in the formation of mucoproteins, which are eliminated in the form of mucous. Further, direct and / or indirect utilization of proteins and lipids for energy needs was also reported [34]. Also, the utilization of proteins in cell repair and organization as causes of their depletion in the tissues cannot be ruled out. The present study showed that chromium induced alterations at the biochemical level, more pronounced changes occurring at the end of $96 \mathrm{~h}$ and thus it is time-dependent. Also, the metal induced alterations in the protein content may probably affect the enzyme mediated bio defence mechanisms of the fish. Future research should focus on the effect of chromium toxicity on bio defence mechanisms of Labeo rohita at cellular and sub cellular levels.

\section{Conclusions}

Acute exposure to hexavalent chromium proved to be highly toxic to Labeo rohita and induced cumulative deleterious effects at various vital functional sites like metabolic rate, hematological indices and biochemical profiles. Though significant changes are observed both at the end of $24 \mathrm{~h}$ and $96 \mathrm{~h}$ exposure periods, these changes are more pronounced at the end of $96 \mathrm{~h}$ suggestive of time-dependent toxicity. The metal induced decrease in the total protein content could possibly affect the enzyme mediated bio defence mechanisms of the fish, which pose a serious threat to human beings by secondary poisoning through food chain. Further studies under sub-acute exposure are required to elucidate the subtle changes that occur in the above parameters under the impact of chromium.

Acknowledgments: The author thank Prof. $M$. Balaparameswara Rao, Department of Aquaculture, Nagarjuna University, Nagarjuna Nagar, Andhra Pradesh, India for his invaluable guidance, providing necessary infrastructural facilities and suggestions in the execution of this work. Thanks are also due to Prof. Y. Anjaneyulu, Director, Institute of Science and Technology, Jawaharlal Nehru Technological University, Hyderabad, India for his valuable inputs and encouragement.

\section{References}

1. Vutukuru, S. S.: Chromium induced alterations in some biochemical profiles of the Indian major carp, Labeo rohita (Hamilton). Bull. Environ. Contam. Toxicol. 2003, 70, 118-123.

2. Ui, J.: The changing chemistry of the Oceans. Almquist and Wiksells, Stockholm, 1972.

3. Langard, S.; Norseth, T.: Chromium. In: Hand Book on the Toxicology of Metals. Friberg, L.; Gunnar, F. N.; Velimir, B. V. (eds). Elsevier-North Holland, Biochemical Press, Netherlands, 1979, pp. 383-394.

4. Ambrose, T.; Cyril Arun Kumar, L.; Vincent, S. Roselyn Lambert.: Biochemical responses of Cyprinus carpio communis to toxicity of tannery effluent. J. Ecobiol. 1994, 6(3), 213-216.

5. Vutukuru, Srinivas, S.; Balaparmeswara, Rao M.: Impact of hexavalent chromium on survival of the frewshwater fish, Sarotherodon mossambicus. $J$. Aqua. Biol., 2000, Vol. 15 (1 and 2), 71-73.

6. Sornaraj, R.; Baskaran, P.; Thanalakshmi, S.: Effects of heavy metals on some physiological 
responses of air breathing fish, Channa punctatus (Bloch). Environ. Ecol, 1995, 13(1), 202-207.

7. Abbasi, S. S.; Kunahmed, T.; Nipaney, P. C.; Soni, R.: Influence of the acidity on chromium toxicity- A study with the teleost, Nuria danricus as model. Poll. Res., 1995, 14 (3), 317-323.

8. Sastry, K. V.; Sunitha, K.: Chronic toxic effects of chromium in Channa punctatus: Biochemical studies. J. Environ. Biol., 1984, 5(1), 53-56.

9. Mahipal Singh.: Hematological responses in a freshwater teleost, Channa punctatus to experimental copper and chromium poisoning. $J$. Environ. Biol., 1995, 16, 339- 341.

10. APHA; AWWA; WPCP: Standard methods for the examination of Water and Wastewater. $20^{\text {th }} \mathrm{ed}$. American Public Health Association, Washington, DC. 1998.

11. Vutukuru, Srinivas, S.; Balaparameswara Rao, M.: Acute toxicity of Chromium to the freshwater teleost fish, Labeo rohita. Ind. J. of Comp. Anim. Physiol. 1996, 14(2), 30-32.

12. Methods for acute toxicity tests with fish, macro invertebrates and amphibians. U.S.E.P.A, E.R.S, EPA 660/3-75-009, 1975, 61 pp.

13. Finney, D. J.: Probit analysis $2^{\text {nd }}$ edition. Cambridge University press, Cambridge England, 1953.

14. Fitch, D. D.: Oxygen consumption in the Prosobranch snail, Viviparous contectoides (Mollusca: Gastropoda) - Effects of weight and activity. Comp. Biochem. Physio.l, 1975, 51A, 815-820.

15. Bailey, N. T. J.: Statistical Methods in Biology. The English Language Book Society: Great Briton, 1959, pp. 200.

16. Mukherjee, K. L.: Medical Laboratory Technology. A procedure manual for routine diagnostics tests, Vol I., Tata-McGraw-Hill, New Delhi, 1988, pp. 48.

17. Kemp Andienne, J. M.; Kits Van Hejningen.: A calorimetric micro method for the determination of glycogen. J. Biochem., 1954, 56, 640-648.

18. Pondey, S. V.; Khan, A. P.; Subramanyam, T. A. V.: Micro determination of lipids and serum fatty acids. Analyst. Biochem., 1963, 6(5), 120-125.

19. Lowry, O. H.; Rosebrough, N. J.; Lewis Farr, A.; Randall, R.: Protein measurement with Folin Phenol Reagent. J. Biol. Chem. 1951, 193, 265-275.

20. Taylor, D.; Maddock, B. G. Mance, G.: The acute toxicity of nine "grey-list' metals (Arsenic, Boron, Chromium, Copper, Lead, Nickel, Tin, Vanadium and Zinc) to two marine fish species, Limanda limanda and Chelon labrosus. Aquatic. Toxicol. 1985, 7, 136-144.

21. Akhilender Naidu, K.; Abhinender Naidu, K.; Ramamoorthy, R.: Histological observations in gills of teleost fish, Sarotherodon mossambicus. Ecotoxicol and Environ Safety, 1983, 5, 455-462.

22. James, R. K.; Sampath, K.; Punithavathi Ponmani, K.: Effect of metal mixtures on activity of two respiratory enzymes and their recovery in Oreochromis mossambicus (Peters). Ind. J. Exp. Biol., 1992, 30, 496-499.

23. Balavenkatasubbiah, M.; UshaRani, A.; Geethanjali, K.; Pyrushottam, K. R.; Ramamurthy, R.: Effect of cupric chloride on oxidative metabolism in the freshwater fish, Tilapia mossambica. Ecotoxicol and Environ. Safety. 1984, 8(3), 289-291.

24. Vutukuru, Srinivas, S.; Balaparameswara Rao, M.: Chromium induced histological alterations in the gill of the freshwater teleost fish, Labeo rohita (Hamilton). Ind. Journal of Comp. Animal Physiol. 1999, 17(1), 31-33.

25. Singh, S. R.; Singh, B. R.: Effect of copper and zinc sulphate on the blood parameters of Mystus vittatus. Matsya. 1982, 8, 1-6.

26. Vincent, S.; Ambrose, T.; Cyril Arun Kumar, L.; Selvanayagan, M.: Heavy metal cadmium influenced anaemia in Catla catla. J. Environ. Biol., 1996, 17(1), 81-84.

27. Sen, G.; Behera, M. K.; Patel, P. N.: Effect of zinc on hemato-biochemcical parameters of Channa punctatus. J .Ecotoxicol. Environ. Monit., 1992, 2, 89-92.

28. Prasanta Nanda.; Milan Kumar Behera.: Nickel induced changes in some hemato-biochemical parameters of a catfish, Heteropneustes fossilis. Environ and Ecol. 1996, 14(1), 82-85.

29. Janardhana Reddy, S.; Kalarani, V.; Tharakanadha, B.; Reddy, D. C.; Ramamurthi, R.: Changes in energy metabolism of the fish, Labeo rohita in relation to prolonged lead exposure and recovery. $J$. Ecotoxicol. Environ. Monit., 1998, 8 (1), 43-53.

30. Johansson-Sjobeck, M. L.; Larrsson, A.: Effect of inorganic lead on $\alpha$-aminolevulinic acid dehydratase activity and hematological variables in Salmo gairdnerii. Arch. Environ. Contam. Toxicol. 1979, 8, 419-431.

31. Dezwaan, A.; Zandee, D. I.: Body distribution and seasonal changes in glycogen content of the common sea mussel, Mytilus edulis. Comp. Biochem Physiol,. 1973, 43, 53-55.

32. Chandravathy Mary; Reddy, S. L. N.: In vivo effects of lead acetate on dehydrogenase activities and metabolites in the freshwater fish, Anabas scandens. J. Ecotoxicol. Environ. Monit., 1995, 5(2), 107-111.

33. Harper, A. H.: Review of Bio Chemistry. $20^{\text {th }}$ ed. Lange Medical Publications Co, California, 1983, pp 1012.

34. Nagai, M.; Ikeda, S.: Carbohydrate metabolism in Fish-1. Effects of starvation and dietary composition on the blood glucose level and haepatopancreatic glycogen and lipid contents in Cyprinus carpio. Bull. Jap. Soc. Scient. Fish, 1971, 37, 404-409.

35. Adelman, I. R.; Smith: Acute toxicity of sodium chloride, pentachlorophenol, guthion and hexavalent chromium to Pimephales promelas and Carassius auratus. J. Fish. Res. Bd. Can. 1976, 33, 203.

36. Reusink, R. G.; Smith, L. L.: Relationship of $96 \mathrm{~h}$ $\mathrm{LC}_{50}$ to lethal threshold concentration of hexavalent chromium, phenol and sodium pentachlorophenate for fathead minnow, Pimephales promelas (Raf). Trans. Amer. Fish. Soc., 1975, 104, 567.

37. Benoit, D. A.: Toxic effects of hexavalent chromium on book trout, Salvelinus fontinalis and rainbow trout, Salmo gairdnerri. Wat. Res. 1976, 10, 497-500. 